\author{
BARBARA KAŁDON \\ Uniwersytet Kardynała Stefana Wyszyńskiego \\ $w$ Warszawie
}

\title{
UBÓSTWO RODZIN CZYNNIKIEM POWSTAWANIA \\ TRUDNOŚCI W FUNKCJONOWANIU SZKOLNYM \\ DZIECI
}

\section{FAMILY POVERTY AS A REASON FOR CHILDREN'S DIFFICULTIES IN FUNCTIONING AT SCHOOL}

\section{Streszczenie}

Problem ubóstwa jest zagadnieniem, którym interesują się różne dyscypliny naukowe, a także instytucje. Szczególnie obszar ten bliski jest pedagogice społecznej współpracującej z innymi dyscyplinami naukowymi. W artykule omówione zostaje fundamentalne środowisko wychowawcze, jaką jest rodzina. W tym wypadku chodzi o sytuację rodziny ubogiej i jej sytuacja w kontekście trudności szkolnych dzieci.

\section{Słowa kluczowe}

Ubóstwo, rodzina, dziecko, trudności, szkoła.

\section{Summary}

The problems of poverty is an issue of interest to many different disciplines and also different institutions. Especially, poverty is closely linked to social pedagogy which collaborates with others on this topic. In this article, the family will be described as the fundamental environment for the upbringing of children with the focus being on the situation of the poor family and the difficulties of the children at school. 


\section{Key words}

Poverty, family, child, difficulties, school.

\section{WPROWADZENIE}

Ubóstwo w Polsce dotyka coraz szerszych grup społecznych, staje się zjawiskiem powszechnym i niebezpiecznym. W literaturze przedmiotu można spotkać wiele różnych definicji na temat ubóstwa. Autorka niniejszego artykułu posłuży się definicją zespołu badaczy: J. Boczonia, W. Toczyńskiego i A. Zielińskiej, którzy twierdzą że „pojęcie ubóstwa w świadomości społecznej funkcjonuje jako brak dostatecznych środków materialnych do życia, jako bieda i niedostatek. Ubóstwo można zdefiniować jako stan poniżej pewnego zmiennego w czasie progu dochodowego lub progu realizacji potrzeb w odniesieniu do jednostki, rodziny lub grupy społecznej."1

\section{DEFINICYJNOŚĆ I PRZYCZYNY UBÓSTWA}

Według A. Kurzynowskiego, ,ubóstwo związane jest z niezaspokojeniem potrzeb na pożądanym poziomie. Podstawą pomiaru tego zjawiska w krajach Wspólnoty jest tzw. operacyjna definicja ubóstwa. Mówi ona, że ubóstwo odnosi się do osób, których środki są ograniczone w takim stopniu, że poziom ich życia obniża się poza akceptowane minimum w kraju zamieszkania."2

Jak pisze P. Kurowski, „ubóstwo jest pojęciem względnym, punktem odniesienia dla jego zmierzenia są kryteria przyjęte dla badanej jednostki lub grupy społecznej. Najczęściej spotykane są kryteria dochodowe. Mają one postać określonych pieniężnie linii ubóstwa, nazywanych też progami lub granicami ubóstwa. W Polsce dla określenia linii ubóstwa

1 J. Boczoń, W. Toczyński, A. Zielińska, Ubóstwo jako zjawisko społeczne oraz przedmiot pracy socjalnej, [w:] T. Pilch, I. Lepalczyk (red.), Pedagogika społeczna, Warszawa 1995, s. 342.

2 A. Kurzynowski, Polityka społeczna, Warszawa 2002, s. 9. 
stosuje się tzw. minimum egzystencji. Jest to wysokość kosztów zaspokojenia potrzeb egzystencjalnych. Jest ono normatywnym modelem zaspokajania potrzeb bytowo konsumpcyjnych na niskim poziomie. Koszyk minimum biologicznego wyznacza najniższy standard życia. Chodzi o wyznaczenie granicy, poniżej której występuje biologiczne zagrożenie życia i psychofizycznego rozwoju człowieka. W koszyku minimum egzystencji znajdują się jedynie wydatki pozwalające na tzw. przeżycie z pominięciem innych potrzeb. Potrzeba utrzymania więzi ze społeczeństwem w tej kategorii nie jest uwzględniona. Potrzeby takie jak wypoczynek, transport i łączność czy udział w kulturze nie istnieją w koszyku minimum egzystencji." 3

Przyczynami powstawania ubóstwa zajmują się obecnie politolodzy, ekonomiści, socjolodzy, filozofowie, pedagodzy, psychologowie, pracownicy socjalni oraz teolodzy. Zwolennicy „twardych” reguł rynkowych, którzy opowiadają się za stosowaniem kategorii ubóstwa absolutnego, jego przyczyn poszukują w niewłaściwym postępowaniu samych ubogich. Jednak nie zawsze winą można obarczyć samych zainteresowanych. Na niską aktywność ubogich w kierunku dokonywania prób podniesienia jakości swego życia mogą bowiem wpływać różne przyczyny: niechęć do ciężkiej pracy, małe doświadczenie, brak kwalifikacji zawodowych poszukiwanych na rynku pracy, patologie życia rodzinnego, ułomności fizyczne lub psychiczne, wyuczona bezradność, wstyd i in.. Wymienia się także pogląd, że mechanizm rynkowy przydzielając niektórym członkom społeczeństwa niedostateczne środki, działa w sposób bezwzględny i krzywdzący. Rynek generuje bezrobocie oraz nadmierne zróżnicowanie płac w zależności od zawodu, miejsca pracy i gałęzi gospodarki. W takim ujęciu fakt uzyskiwania zbyt niskich dochodów nie jest winą ubogich lecz bezdusznego systemu społeczno-gospodarczego, który nie uwzględnia potrzeb ludzi, a jedynie ich przydatność do gospodarki. ${ }^{4}$

$\mathrm{Z}$ danych M. Jarosza za główne przyczyny ubóstwa w Polsce można uznać:

3 P. Kurowski, Koszyki minimum socjalnego i minimum egzystencji-dotychczasowe podejście, „Polityka społeczna” 2004 nr 4, s. 32-33.

4 J. Boczoń, W. Toczyński, A. Zielińska, Ubóstwo jako..., dz. cyt., s. 342. 
- bezrobocie pełne lub częściowe,

- niski poziom dochodów,

- niskie wykształcenie,

- wielodzietność,

- zła sytuacja mieszkaniowa,

- rozpad rodziny. ${ }^{5}$

Słusznym wydaje się podkreślić fakt, wynikający z badań, który dowodzi, że w rodzinach ubogich jeden z wyżej wymienionych czynników ubóstwa, np. bezrobocie, może spowodować inny czynnik patologizacji życia społecznego czy prywatnego, np. rozpad rodziny. Na ten temat trafnie pisze T. Rymarz: „Stosunkowo często negatywnym zmianom ulega charakter kontaktów bezrobotnego ojca czy matki z współmałżonkiem i dziećmi. W rodzinach tych łatwo dochodzi do wybuchów złości, kłótni, konfliktów, rzadziej ma miejsce wzajemne zrozumienie i wsparcie. Im dłużej bezrobotni pozostają bez pracy, tym silniej zaznacza się u nich zaniżona ocena własnej wartości. Często dotychczasowy optymizm ojca czy matki zostaje zastapiony zniechęceniem, frustracją agresją. Wyniki przeprowadzonych badań upoważniają do stwierdzenia, że długotrwałe bezrobocie powoduje wzrost poziomu neurotyzmu i negatywnie wpływa na więź psychiczną w małżeństwach."

Oprócz rozwodów i separacji ubóstwo często powoduje różne inne rodzaje patologii społecznej, między innymi alkoholizm, narkomanię, samobójstwa, prostytucję, pasożytnictwo społeczne i inne. Zjawiska te potrzebują rozwiązań systemowych.

\section{ZWALCZANIE UBÓSTWA I WYRÓWNYWANIE SZANS SZKOLNYCH DZIECI}

Rozważając możliwości realizacji systemowego podejścia w zwalczaniu ubóstwa, T. Kowalak podaje, że „ubóstwo należy do tych proble-

\footnotetext{
5 M. Jarosz, Nierówności społeczne, Warszawa 1984, s. 271.

6 T. Rymarz, Psychospoteczne aspekty funkcjonowania rodzin z problemem bezrobocia, [w:] S. Badora, R. Stojecka-Zuber (red.), Pedagogika wobec problemów opieki i resocjalizacji, Tarnobrzeg 2007, s. 269.
} 
mów społecznych, w których przezwyciężaniu doniosła rola przypada administracji rządowej, prowadzonej przez nią polityce gospodarczej, polityce zatrudnienia oraz polityce ubezpieczeń społecznych. Dotychczasowe rozwiązania prawne i instytucjonalne, przyjęte w Polsce wskazuja, że mimo dużych nakładów na państwową ochronę socjalną, skala i dynamika ubóstwa jest bardzo wysoka."

Jak słusznie zauważają autorzy J. Boczoń, W. Toczyński, A. Zielińska, „konkretna walka z ubóstwem oparta jest na trzech kierunkach działań:

- pierwszym jest kształcenie zawodowe i oświata. Stwierdza się fakt bezrobocia, które jest silnym czynnikiem ubożenia, a może być w istotny sposób łagodzony przez wzmocnienie inicjatyw w zakresie kształcenia i wychowania,

- drugim kierunkiem działania jest stworzenie warunków korzystnej komunikacji społecznej i informacji ludzi ubogich, nie powinni oni pozostawać na marginesie i żyć w ukryciu, prawo do komunikacji i informacji służy ujawnianiu problemów ludzi ubogich, a z drugiej strony uczula społeczeństwo na te zagadnienia i pozwala społecznościom lokalnym na identyfikację ubóstwa jako problemu wspólnoty,

- trzecim kierunkiem przeciwdziałania ubóstwu są gwarantowane dochody najniższe, które powiązane są z zawodowym i społecznym powrotem do społeczeństwa. Oznacza to stosowanie różnorodnych środków pomocy, bardzo ważnym kierunkiem walki z ubóstwem jest praca w środowisku i samopomoc." 8

Grono ludzi ubogich żyjących w bardzo trudnych warunkach wciąż się powiększa, nie mają oni szans na godne życie. Ubóstwo ogranicza bowiem potrzeby, aspiracje, marzenia. Bieda w domu oznacza: lęk, wstyd, niedożywienie, monotonię, brak radości i realnych perspektyw. Im rodzina uboższa tym trudniej wywiązać się z przynależnych do niej funkcji, tym mniejsze są możliwości wychowania, kształcenia i rozwoju dzieci.

Zazwyczaj to właśnie rodzina jest pierwszym środowiskiem życia społecznego człowieka. W niej mają początek biografie ludzkie. Jakie

7 T. Kowalak, Kwestie ubóstwa, [w:] A. Rajkiewicz, T. Kowalak, E. Leś (red.), Polityka społeczna, Warszawa 1998, s. 143- 144.

8 J. Boczoń, W. Toczyński, A. Zielińska, dz. cyt., s. 361. 
one będą zależy od wielu czynników. Rodzina wywiera istotny wpływ na zachowanie się jednostek, ich stosunku do innych osób, świata wartości, systemu norm, wzoru postępowania. Od niej zależy w dużej mierze szczęście i powodzenie w całym życiu.

Rodzina, jak pisze T. Kukołowicz, ,jest kształtem rzeczywistości, prawda o niej, jej trwanie jako wspólnoty jest uzależnione od spełniania zadań wobec niej. Realizacja jej zadań tworzy zwykłe codzienne życie. To właśnie życie codzienne, zachowane w nim proporcje między troską o zaspokojenie potrzeb materialnych, psychicznych i duchowych stanowi zarazem treść, jak i sposób, metody wychowania." Jeśli jednak ta równowaga zostanie zachwiana, dochodzi w rodzinie do blokady potrzeb. Według J. Maciaszkowej, „w rodzinie ubogiej często są niezaspokojone nawet te najbardziej podstawowe potrzeby takie, jak: bezpieczeństwo fizyczne i psychiczne, afiliacja czy potrzeba miłości, natomiast potrzeby biologiczne stają się treścią życia rodzinnego." 10

W wielu polskich biednych rodzinach nie udaje się zaspokoić na właściwym poziomie podstawowej potrzeby odżywiania, bowiem ze względów oszczędnościowych przygotowuje się mało wartościowe pokarmy, co w konsekwencji może prowadzić do stanu niedożywienia, szczególnie niebezpiecznego w okresie dzieciństwa. Problem niedożywienia dzieci i jego psychologiczne konsekwencje nawet zainspirowały niektórych naukowców z tej dziedziny wiedzy do tworzenia nowego pojęcia pedagogicznego ,pedagogika dziecięcego talerza”.

M. Kaliszewska w swoim artykule tak uzasadnia potrzebę opracowania w/w problematyki: ,„pedagogika dziecięcego talerza to - rzecz jasna - metaforyczna nazwa możliwej do zaprojektowania subdyscypliny pedagogiki, której zadaniem byłoby uzmysłowienie środowiskom pedagogicznym braków w rozumieniu biologicznych potrzeb dziecka, a więc też żywieniowych oraz konieczności edukowania także rodziców w tym zakresie. Gdyby tak rozumiana pedagogika miała zaistnieć, to musiałaby wykorzystać znaczące obszary innych subdyscyplin pedago-

\footnotetext{
9 T. Kukołowicz, Rodzina wychowuje, Stalowa Wola 2001, s. 197.

10 J. Maciaszkowa, Z teorii i praktyki pedagogiki opiekuńczej, Warszawa 1991, s. 38.
} 
gicznych (np. teorii wychowania, dydaktyki ogólnej) oraz innych nauk, współdziałających z pedagogiką, jak np. biologii."11 Zasługą Autorki tego artykułu jest zauważenie ścisłego związku między kwestią wyżywienia uczniów a kwestią ich psychospołecznego funkcjonowania oraz rozwoju. Z tego powodu M. Kaliszewska wypowiada się tak: „sposób zaspokajania i jakość przekąsek są także elementami kreującymi tożsamość uczniów. Dlatego pieniądze, otrzymywane na drugie śniadanie, wolą wydać na modne zakąski, niż zwykłą bułkę, gdyż w ten sposób polepszają i tworzą swój wizerunek i mogą brać udział w koleżeńskich wymianach różnych drobiazgów dołączonych do kupowania słodyczy i przekąsek." 12 Rodziny, żyjące w ubóstwie, mające problemy w realizacji podstawowych potrzeb dziecka, często nie mogą jego nakarmić. W związku z tym, bardzo często nie są w stanie przekazać w sposób prawidłowy zwyczajów, obyczajów czy podstawowych zasad dobrego wychowania obowiązujących w danym społeczeństwie, ponieważ muszą martwić się o codzienne przetrwanie swojej rodziny.

Inną ewentualną konsekwencją wychowywanie się dziecka w rodzinie ubogiej jest opóźnienie w emocjonalnym i społecznym rozwoju dziecka. Dziecko z rodziny ubogiej ma znaczne trudności w realizacji funkcji emocjonalno-ekspresyjnej, polegające na przeżywaniu pewnego dystansu wobec rówieśników oraz negatywnych uczuć w kontaktach z nimi, spowodowanych wstydem i zaniżoną samooceną. Te uczucia szczególnie nasilają się u dzieci z niezamożnych rodzin w stosunku do uczniów, posiadających piękne i niedostępnie dla nich rzeczy (ładne ubrania i plecaki, drogie pióra i inne materiały biurowe, nowoczesne komórki i in.), gdyż czują się gorsze na ich „luksusowym” tle. W ten sposób tworzy się sztuczny dystans psychologiczny między rówieśnikami, spowodowany ewidentną różnicą między dziećmi, uczęszczającymi do tej samej klasy, ale wywodzącymi się z różnych pod względem statusu społecznego i standardu życia rodzin.

${ }^{11}$ M. Kaliszewska, Pedagogika dziecięcego talerza - aspekt teoretyczny, dydaktyczny $i$ socjalny, [w:] S. Badora, R. Stojecka-Zuber (red.), Pedagogika wobec problemów opieki i resocjalizacji, Tarnobrzeg 2007 s. 107.

12 Tamże s. 109. 
B. Kulikowska mówi o wpływie warunków ekonomicznych na funkcjonowanie dzieci w szkole także w kontekście sukcesu szkolnego: „Dzieci z rodzin, dotkniętych niedostatkiem, wychowują się w atmosferze napięcia i nierówności, często mają problemy w szkole, ich szanse w porównaniu z rówieśnikami już na samym początku kariery szkolnej są mniejsze, często one są skazane na niepowodzenia. Trudna sytuacja materialna w rodzinie powoduje często brak zainteresowania rodziców postępami w nauce szkolnej. Rodzice nie kontrolują zeszytów dziecka, nie pomagają mu w nauce, nie przychodzą na zebrania, organizowane przez wychowawców. Zabezpieczenie skromnego bytu materialnego tak ich pochłania, że wszystko inne staje się nie ważne."13

$\mathrm{Z}$ uwagi na to, iż warunki finansowe często decydują w dużym stopniu o dostępie do edukacji, mogą być jedną z barier w rozwoju młodego człowieka, który cierpi na syndrom zawężonej informacji, gdyż szczupła pula pieniędzy blokuje dostęp do jej źródeł. Taka przykra sytuacja jest spowodowana tym, iż aby utrzymać się rodziny ubogie są zmuszone do zaoszczędzania na wszystkim: na codziennej prasie, czasopismach, książkach, aż po elektroniczne źródła wiedzy. Z tegoż powodu uniemożliwiony jest udział dzieci w płatnych kółkach zainteresowań, gdzie uczniowie mogą również dowiedzieć się dużo ciekawych informacji oraz kształtować interesujące ich umiejętności artystyczne, sportowe i in. (na co bez większych problemów mogą sobie pozwolić dzieci wywodzące się z rodzin o przeciętnym i wysokim standardzie życia).

Tak więc dzieci z rodzi ubogich już na starcie pozbawione są szans na uniknięcie nierówności. $Z$ pojęciem nierówności szans edukacyjnych wiąże się zjawisko startu społeczno-edukacyjnego.

St. Kawula pisze, że „start szkolny, życiowy i społeczny stanowi decydujący składnik procesów selekcji lub awansu edukacyjnego, zawodowego i kulturowego młodych pokoleń. W skrajnych przypadkach prowadzi on do swoistego naznaczenia i wykluczenia. Dotyczy on problemu optymalizacji rozwoju psychofizycznego, intelektualnego, spo-

${ }_{5}^{13}$ B. Kulikowska, Gdy szkoła sprawia trudności, „Nowe w szkole” $2003 \mathrm{nr} 11$ s. 5-9. 
łecznego i kulturalnego dzieci i młodzieży z różnych grup społecznych i środowisk - jako intensyfikację ich szans. Odnosi się to zwłaszcza do środowisk społecznie, kulturowo i socjalnie zaniedbanych, pod wieloma względami zróżnicowanych od obfitości do niedostatku i biedy. Te ostatnie można nazwać obszarami ryzyka społecznego i edukacyjnego. O starcie społeczno-edukacyjnym dzieci decyduje w znacznym stopniu dynamika życia rodzinnego, na które składa się tradycja awansu kulturalnego i oświatowego w rodzinie i aktualna pozycja społeczno-zawodowa rodziców. Wykształceni rodzice i rodziny właściwie spełniające swe funkcje opiekuńczo-wychowawcze i inne, osiagają przyśpieszenie rozwoju intelektualnego i społecznego dzieci. Efekty są lepsze, gdy czynią to świadomie, gdy pełnią racjonalną opiekę, ukierunkowują swe dzieci ku wartościowym formom uczestnictwa w kulturze. Tak się dzieje przede wszystkim w rodzinach inteligenckich i środowiskach kulturowo i materialnie zasobnych. Poziom ich umysłowego i kulturowego rozwoju różni się od wskaźników tych dzieci, które wzrastają w rodzinach o niskiej kulturze i złych warunkach materialnych, w atmosferze zaniżonej refleksji ogólnej i pedagogicznej. ${ }^{14}$

\section{PODSUMOWANIE}

Reasumując, należy zgodzić się z poglądami Z. Ostrihanskiej, która przywiązuje ogromne znaczenie do kwestii społecznego wsparcia dla rodzin zagrożonych, w tym - ubóstwem. Uważa bowiem, że opinia publiczna powinna być szczególnie uczulona na potrzeby tych rodzin, zwłaszcza rodzin ubogich. Informacje o trudnej sytuacji tych rodzin powinny docierać do właściwych instytucji i organizacji, oraz osób mających za zadanie niesienia pomocy. „, Chodzi o to, by wiedzy tej towarzyszyło staranie o zrozumienie sytuacji dzieci w danej rodzinie i w razie potrzeby zwrócenie się o pomoc profesjonalną." ${ }^{15}$ Będzie to służyło nie

\footnotetext{
14 St. Kawula, Start społeczno-edukacyjny [w:] Elementarne pojęcia pedagogiki społecznej (red.) D. Lalak, T. Pilch, Warszawa 1999 s. 278-280

15 Z. Ostrihanska, Spoteczne wsparcie dla rodzin zagrożonych [w:] Pomoc rodzinie dysfunkcyjnej (red.) B. Kałdon, Stalowa Wola 2006, s. 31.
} 
tylko wyrównywaniu szans edukacyjnych dzieci ubogich w stosunku do rówieśników, wywodzących się z rodzin o właściwym poziomie życia, ale również okaże się też bardzo pożyteczne w kontekście szeroko rozumianej profilaktyki społecznej.

\section{BIBLIOGRAFIA}

Boczoń J., Toczyński W., Zielińska A., Ubóstwo jako zjawisko spoteczne oraz przedmiot pracy socjalnej, [w:] T. Pilch, I. Lepalczyk (red.), Pedagogika społeczna, Warszawa 1995.

Jarosz M., Nierówności spoleczne, Warszawa 1984.

Kawula S., Start społeczno-edukacyjny, [w:] D. Lalak, T. Pilch (red.), Elementarne pojęcia pedagogiki społecznej, Warszawa 1999.

Kaliszewska M., Pedagogika dziecięcego talerza-aspekt teoretyczny, dydaktyczny i socjalny, [w:] S. Badora, R. Stojecka-Zuber (red.), Pedagogika wobec problemów opieki i resocjalizacji, Tarnobrzeg 2007.

Kowalak T., Kwestie ubóstwa (w) A. Rajkiewicz, T. Kowalak, E. Leś (red.), Polityka społeczna, Warszawa 1998.

Kurzynowski A., Polityka spoleczna, Warszawa 2002.

Kukołowicz T., Rodzina wychowuje, Stalowa Wola 2001.

Kurowski P., Koszyki minimum socjalnego i minimum egzystencji dotychczasowe podejście, „Polityka społeczna” 2004 nr 4.

Kulikowska B., Gdy szkota sprawia trudności, „Nowe w szkole” $2003 \mathrm{nr} 11$.

Maciaszkowa J., Z teorii i praktyki pedagogiki opiekuńczej, Warszawa 1991.

Ostrihanska Z., Spoleczne wsparcie dla rodzin zagrożonych, [w:] B. Kałdon (red.), Pomoc rodzinie dysfunkcyjnej, Stalowa Wola 2006.

Rymarz. T., Psychospoteczne aspekty funkcjonowania rodzin z problemem bezrobocia, [w:] S. Badora, R. Stojecka-Zuber (red.), Pedagogika wobec problemów opieki i resocjalizacji, Tarnobrzeg 2007. 